\title{
Implicit Messages in Memes During the Covid-19 Pandemic
}

\author{
Juanda Juanda \\ Program Studi Sastra Inggris, Fakultas Ilmu Budaya, \\ Universitas Komputer Indonesia \\ Email:juanda@email.unikom.ac.id
}

\begin{abstract}
The purpose of this study is to try to get the message contained in memes during the covid-19 pandemic. The method used is the descriptive method, which describes the messages contained in memes during the covid-19 pandemic. Data sources are taken from online sources such as https:/9gag.com/gag/amPbGrX. The results obtained are that during the COVID-19 pandemic, the community must maintain the health protocol. The impact of this research is that linguistic phenomena can occur under certain conditions in society. The recommendation from this article is that the community must be able to adapt to the conditions that occur around it, such as the emergence of the COVID-19 pandemic case by looking at the communication delivered through social media.
\end{abstract}

Keywords: pandemic, meme, message

\section{INTRODUCTION}

Every speech act contains intent or illocutionary, either direct illocutionary or direct illocutionary. Illocutionary is known as the act of doing something, where there is a certain intention behind the utterance sentence to do something. Perlocutionary is known as the act of affecting someone, where an utterance can affect or have an effect on the hearer. When someone says something, there is an implied message in his speech that has its meaning and intention. This is known as an illocutionary act in speech acts theory. Therefore Austin, [1] defines an illocutionary act as an action taken by the speaker is saying something. In other words, the speaker has another meaning through his speech.

In illocutionary speech acts, when speakers do speak, their speech also produces a function. At the time of performing speech acts, they have a specific purpose when saying an utterance such as asking, offering, ordering, ordering. This paper tries to describe the meaning contained in the expression of language through memes. Previous research that discusses illocutionary acts has been carried out by Adhiguna [2] which discusses elocutionary, illocutionary, and perlocutionary speech acts in the Indonesian language learning process. Other research was done by Susan with the title "Pragmatic Analysis in Using Advertising Language".

\section{METHOD}

The method used is a descriptive method by taking some of the utterances in the meme and then looking at the implicit meaning in the speech. Data sources were taken from sources such as https://9gag.com/gag/amPbGrX in April 2021.

\section{RESULT AND DISCUSSION}

\subsection{Result}

Based on the memes discussed, several implicit meanings to be conveyed through the memes were found, such as disappointment because of PPKM which has an impact on earning a living. Contradictory meanings show the success of the government in implementing PPKM, but on the other hand, the community must suffer the consequences of government policies. Another complaint depicted in the meme is that it is difficult to return to the village. Another thing implicitly is that the meme provides a very scary picture of conditions during a pandemic.

\subsection{Discussion}

The following are findings based on the analysis that has been carried out on memes. 
Figure 1

PPKM

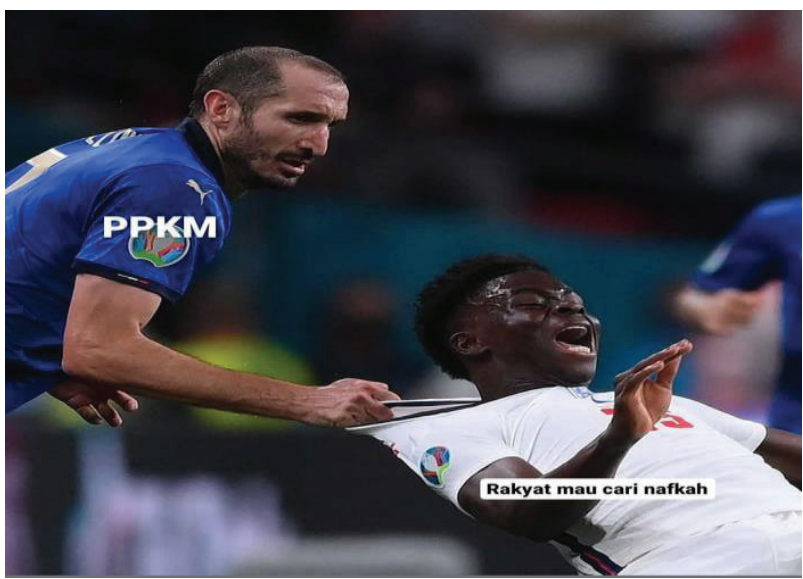

Discussion: The meme illustrates that the PPKM held by the government is currently disturbing the people to earn a living because of the border regulations that the people must follow. The implicit meaning of the meme is that it is representative whose function is to complain.

Figure 2

Pandemic in RI

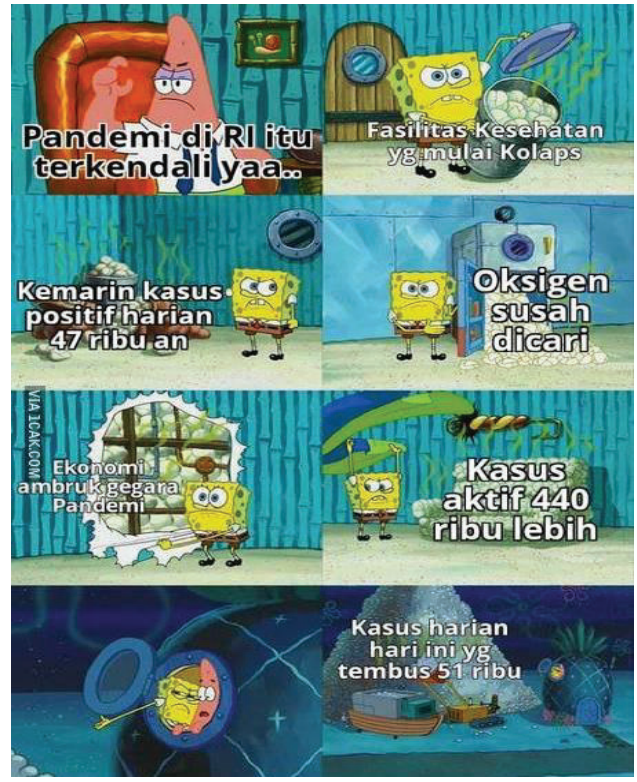

Discussion: The meme compares the comments of one of the state officials in the form of "the pandemic in Indonesia is under

\section{AKIBATNYA...}

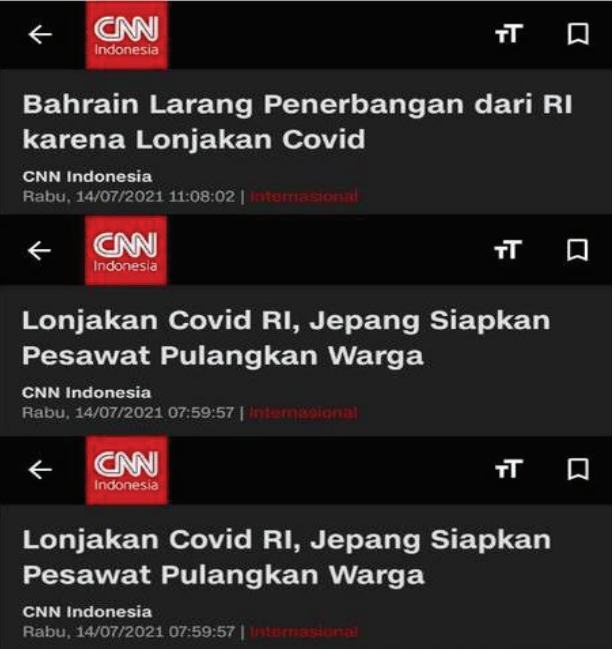

control, right ..," with the conditions that are actually happening at this time. The implicit meaning in the meme is in the form of 
representatives whose function is to conclude.

Figure 3

\section{Extended PPKM}

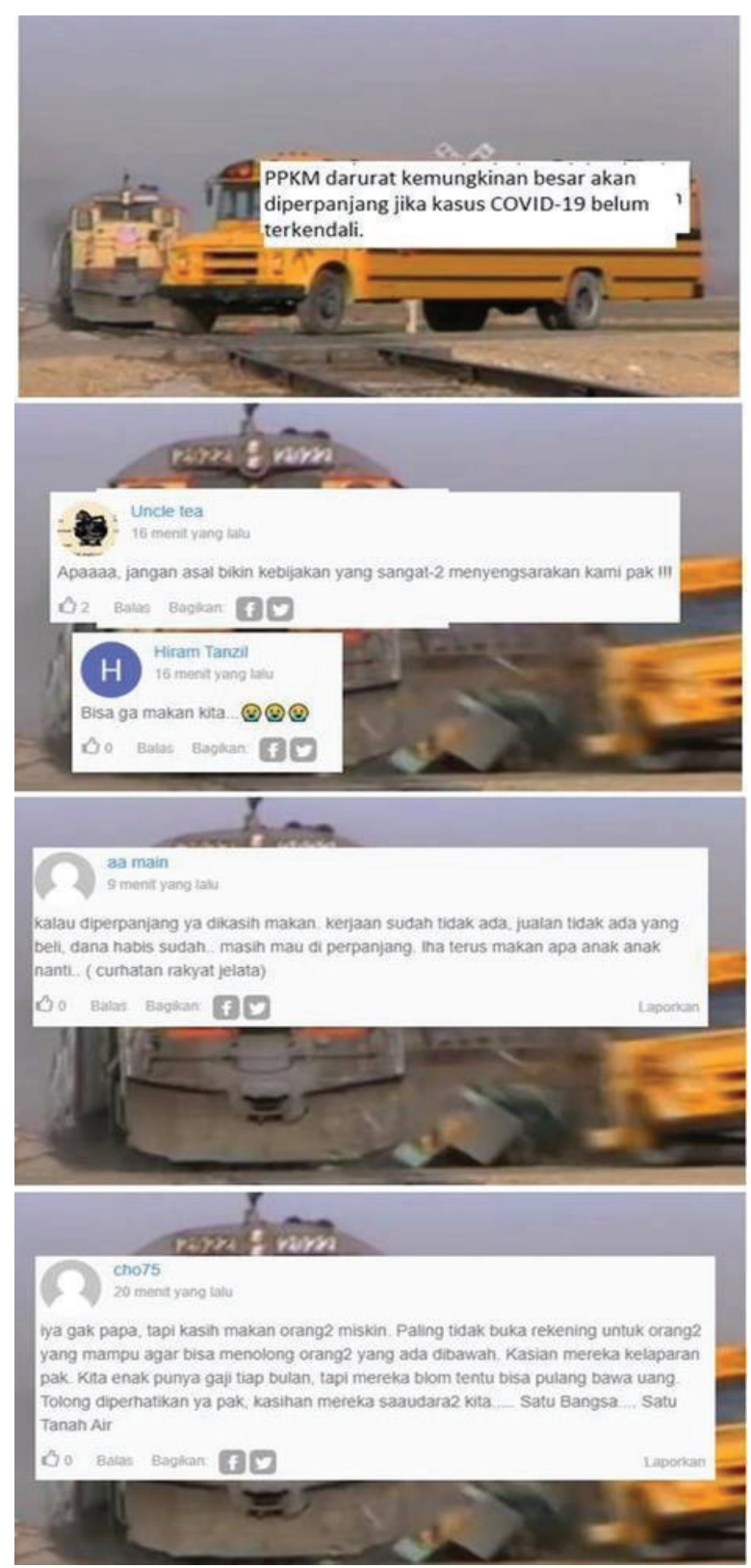

Discussion: The meme describes the public's reaction to the PPKM news which may be extended. The implicit meaning is that people complain about the existence of PPKM, including representatives whose function is to complain. 
Figure 4

Online Lecture

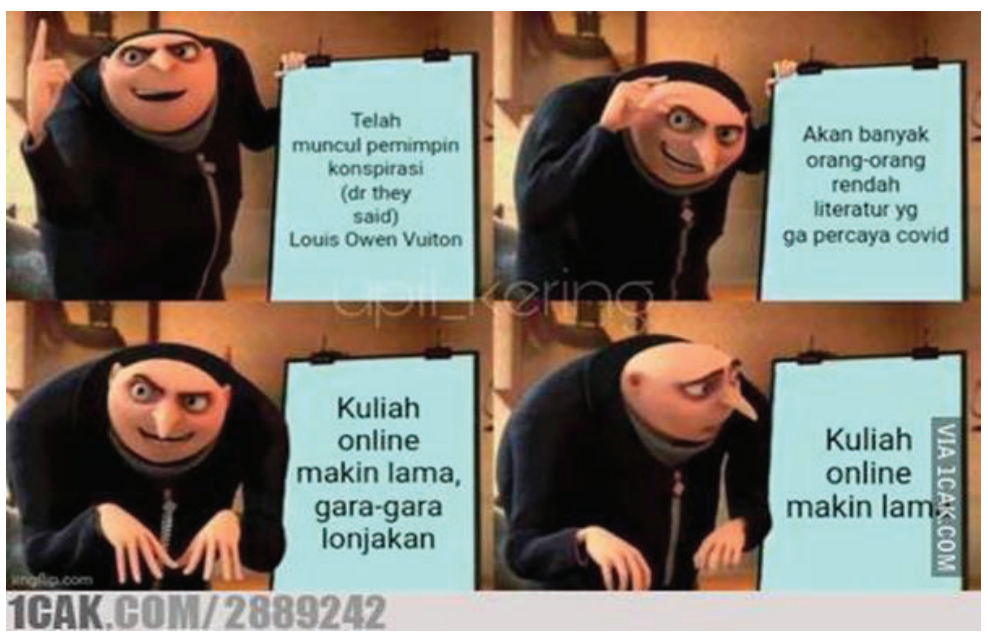

Discussion: The meme describes the student's reaction to the reality that is currently happening in Indonesia. The bottom right image shows a sad expression because online lectures are getting longer. The implicit meaning of this meme includes that representatives are complaining.

Figure 5

Bear Milk

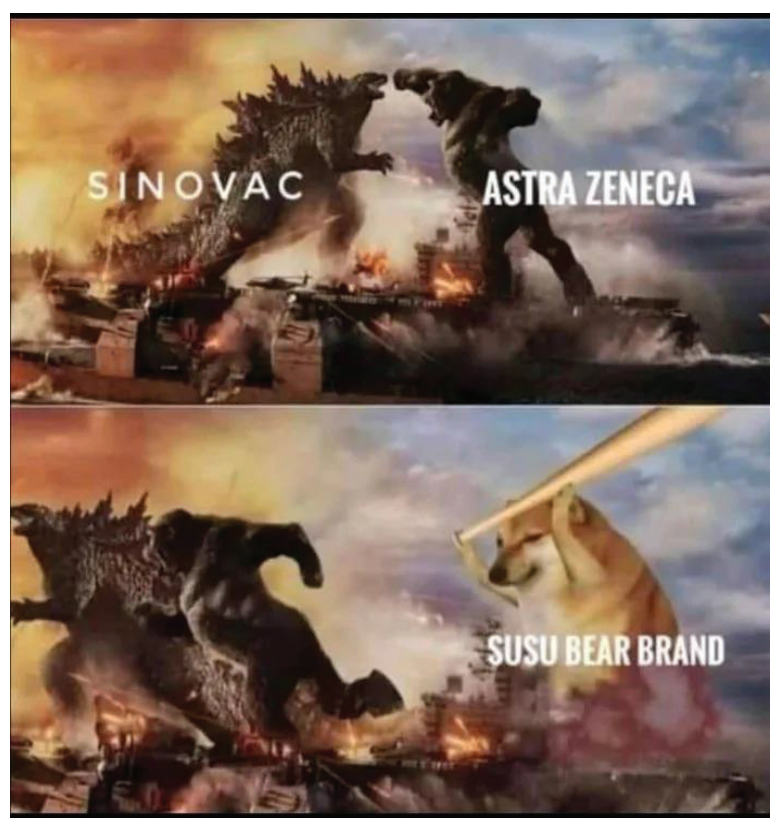


Discussion: The meme illustrates that compared to available vaccines, the power of bear brand milk is more effective in preventing the spread of the coronavirus in the body, which many people believe, even though the news is not basic or a myth. The meaning of this meme includes representatives whose function is to state.

Figure 6

Go Home
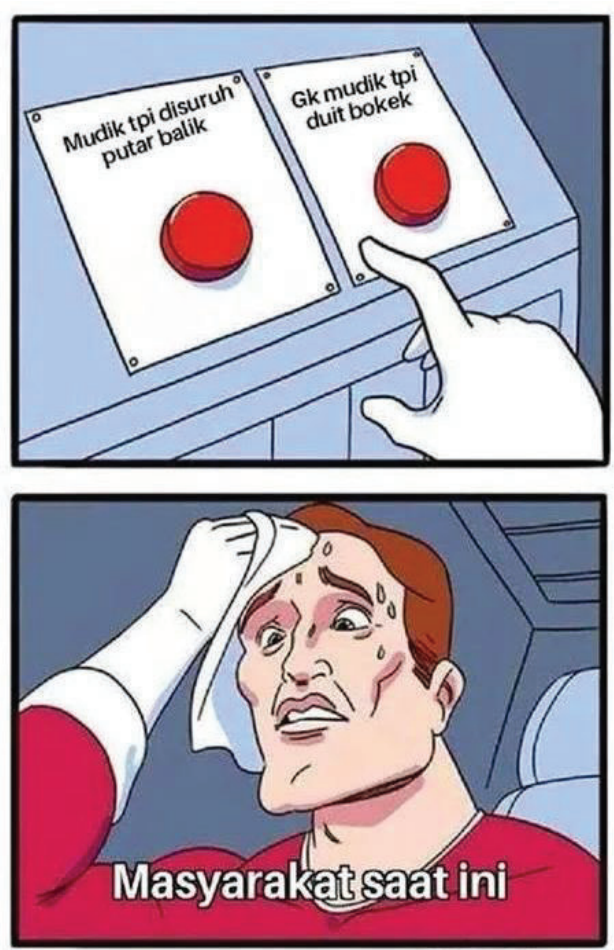

Discussion: The meme describes people who are confused about going home because they have no money due to the coronavirus outbreak, but if they force themselves to return home, they will be ordered to turn back because of the 2021 homecoming ban. The meaning of this meme includes representatives whose function is to complain. 
Figure 7

Government

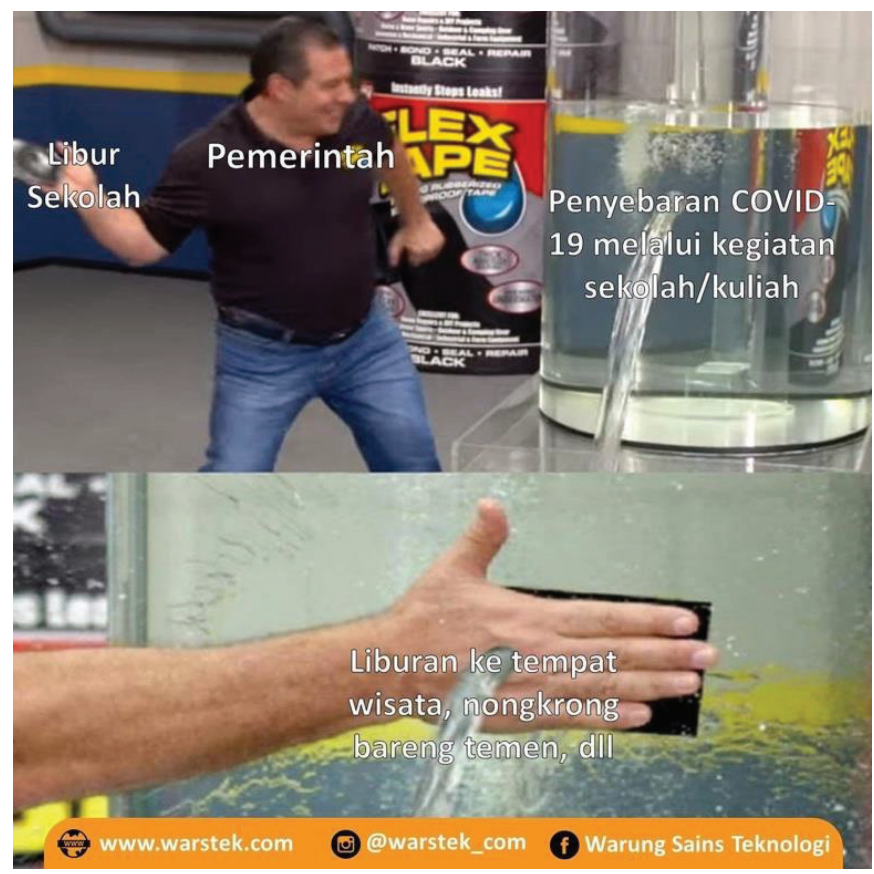

Discussion: The meme illustrates the government's actions to reduce the spread of the covid-19 virus through school activities that are futile because they are not used properly to stay at home. The implicit meaning of this meme includes that representatives function to complain.

Figure 8

New Normal

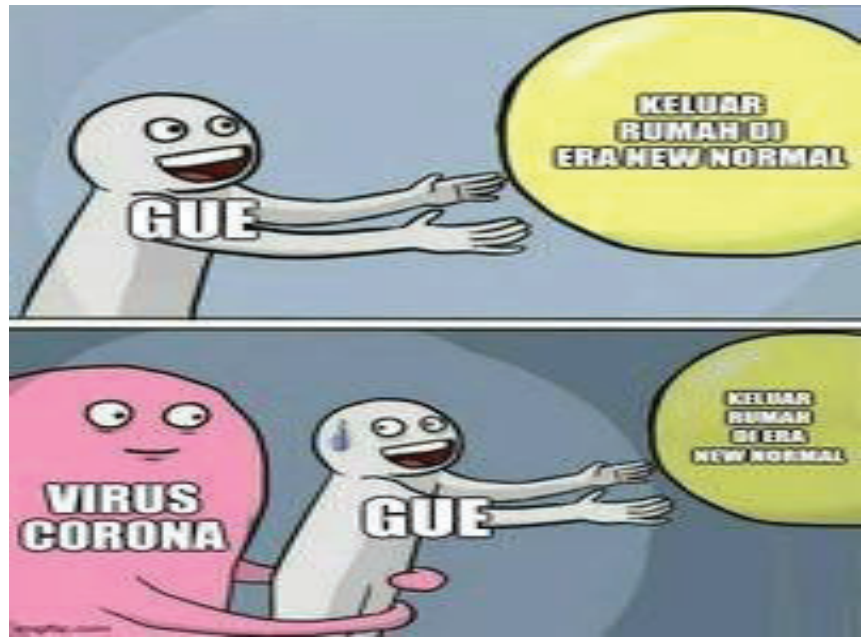


Discussion: The meme illustrates people who want to leave the house but must always be vigilant due to the current corona virus outbreak. The implicit meaning of this meme includes representatives whose function is to complain.

Figure 9

Scare

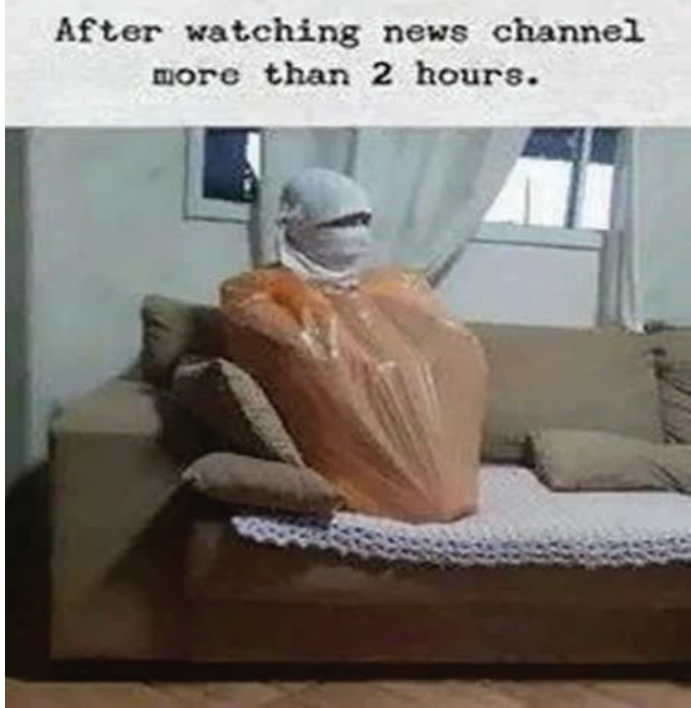

Discussion: The meme illustrates people who are scared after watching the scary news about the corona virus. The implicit meaning in this meme includes representatives whose function is to state.

Figure 10

Covid Impact

\section{Dampak COVID-19 di} Indonesia

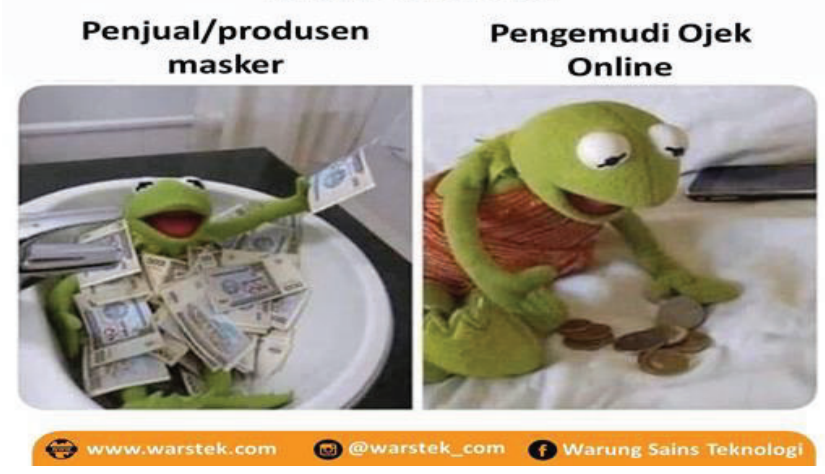


Discussion: The meme compares two conditions that occurred due to the coronavirus outbreak. Mask sellers/producers become rich because masks are objects that must be used so that their sales increase, while the income of online motorcycle taxi drivers decreases because people who do activities outside the home decrease. The implicit meaning in this meme includes representatives whose function is to complain.

\section{CONCLUSION}

Memes can provide an overview of certain situations that occur in society. The language utterances conveyed by the author may vary. Expression of language can be done through memes, comics, banners and so on. Through this meme, people can also express their aspirations indirectly. The content of the meme can be in the form of criticism through the expression of felt complaints. In the memes analyzed, more implicit meanings were found in the form of complaints representatives. This is following the current situation, namely the COVID-19 pandemic. Memes can also inspire policymakers in deciding by looking at the phenomena described in a meme.

\section{REFERENCES}

[1] Austin, J. . 1962. How to Do Things with World. London: Oxford University Press.

[2] Adhiguna, I Made Pradipta. 2019. "Analisis Tindak Tutur Lokusi, Ilokusi, dan Perlokusi dalam Proses Pembelajaran Bahasa Indonesia", Jurnal Bakti Saraswati, Vol.8, No. 2. 